CLINICAL STUDY

\title{
Identification and functional characterization of loss- of-function mutations of the calcium-sensing receptor in four Italian kindreds with familial hypocalciuric hypercalcemia
}

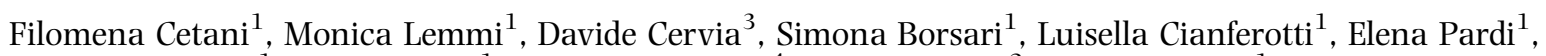
Elena Ambrogini ${ }^{1}$, Chiara Banti ${ }^{1}$, Edward M Brown ${ }^{4}$, Paola Bagnoli ${ }^{2}$, Aldo Pinchera ${ }^{1}$ and Claudio Marcocci $^{1}$

${ }^{1}$ Department of Endocrinology and Metabolism and ${ }^{2}$ Unit of General Physiology, Department of Biology, University of Pisa, 56100 Pisa, Italy, ${ }^{3}$ Department of Environmental Sciences, University of Tuscia, Viterbo, Italy and ${ }^{4}$ Endocrine-Hypertension Division, Department of Medicine, Brigham and Women's Hospital, Boston, Massachusetts, USA

(Correspondence should be addressed to C Marcocci who is now at Dipartimento di Endocrinologia e Metabolismo, Università di Pisa, Via Paradisa 2, 56124 Pisa, Italy; Email: c.marcocci@endoc.med.unipi.it)

\begin{abstract}
Objective: Identification and characterization of calcium-sensing receptor (CASR) mutations in four unrelated Italian kindreds with familial hypocalciuric hypercalcemia.

Design: Clinical evaluation and genetic analysis of CASR gene. Functional characterization of mutated CASRs.

Methods: Direct sequencing of CASR gene in genomic DNA. Studies of CASR-mediated increases in cytosolic calcium concentration $\left[\mathrm{Ca}^{2+}\right]_{\mathrm{i}}$ in CASR-transfected COS-7 cells in vitro.

Results: Four unreported heterozygous CASR mutations were identified, including three missense (H595Y, P748H, and C765W) and one splice site (IVS2 + 1G >C) mutation. The H595Y, P748H, and $\mathrm{C} 765 \mathrm{~W}$ mutant receptors, although expressed at normal levels on the cell surface, showed a reduced response in $\left[\mathrm{Ca}^{2+}\right]_{\mathrm{i}}$ relative to the wildtype (WT) CASR to increasing extracellular calcium concentrations. Cotransfection experiments showed that the $\mathrm{H} 595 \mathrm{Y}$ and P748H mutants did not affect the apparent affinity of the WT CASR for calcium, suggesting that they do not exert a dominantnegative effect. On the other hand, the co-transfected $\mathrm{C} 765 \mathrm{~W}$ mutant decreased the maximum response of the WT CASR to calcium, suggesting that it may reduce the effective concentration of the normal CASR on the cell surface or impair its maximal signaling capacity.

Conclusions: Four CASR mutations were identified. The reduced functional responses to extracellular calcium and normal expression of the mutant receptors suggest that conformational changes account for altered CASR activity. Moreover, a reduced complement of normal CASRs in these heterozygous patients, perhaps combined with a mutant receptor-induced decrease in maximal activity of the WT receptor, may contribute to defective calcium-sensing in vivo.
\end{abstract}

European Journal of Endocrinology $160481-489$

\section{Introduction}

Familial hypocalciuric hypercalcemia $(\mathrm{FHH})$ is a rare disorder inherited as an autosomal dominant trait with a high penetrance of over $90 \%$, characterized by lifelong, mild to moderate asymptomatic hypercalcemia, relative hypocalciuria, and inappropriately normal PTH levels (1). Patients with FHH exhibit mild to moderate resistance of the parathyroid glands to the inhibitory effects of $\mathrm{Ca}^{2+}$ on PTH secretion, resulting in an increase in the 'set-point' of $\mathrm{Ca}^{2+}$-regulated PTH secretion (2).

The cloning of the calcium-sensing receptor (CASR) gene has permitted clarification of the molecular basis of FHH. The CASR is a G-protein-coupled receptor that senses small perturbations in the level of extracellular
$\mathrm{Ca}^{2+}\left[\mathrm{Ca}^{2+}\right]_{\mathrm{o}}$ and modulates the functions of parathyroid and kidney appropriately so as to normalize $\left[\mathrm{Ca}^{2+}\right]_{0}$. On the cell surface, the CASR forms disulfidelinked dimers through cysteine residues within its extracellular domain and the dimerization has functional implications (3).

Heterozygous loss-of-function mutations, mainly scattered throughout the extracellular domain of the CASR, are responsible for most cases of FHH. The majority of mutations are missense (4-6), with a few nonsense (7-9) and splice site mutations (10) as well as an Alu insertion in one family $(11,12)$. Functional in vitro studies have shed light on the mechanisms responsible for the resistance of the parathyroid gland and kidney to calcium. Some mutations produce receptors that do not reach the cell surface and, 
therefore, the number of active, cell surface receptors is $\sim 50 \%$ of that in normal subjects. This interpretation has been supported by the $\sim 50 \%$ reduction in the expression of the normal CASR in the parathyroid glands and kidneys of mice heterozygous for knockout of the CASR gene (13). Other mutations produce receptors that reach the cell surface and exert a dominantnegative action on the wildtype (WT) CASR. About onethird of $\mathrm{FHH}$ kindreds do not have mutations in the coding region or splice sites of the CASR gene, and other causes of hypocalciuric hypercalcemia, such as autoantibodies to the CASR, resulting in a condition called autoimmune hypocalciuric hypercalcemia $(14,15)$, or abnormalities at one of the other two FHH loci on chromosome 19 have been identified $(16,17)$.

We describe four unrelated Italian kindreds with $\mathrm{FHH}$ caused by mutations of the CASR gene and characterize the functional properties of three of these mutant receptors.

\section{Subjects and methods}

\section{Families}

All probands and participating family members underwent genetic and biochemical studies, which included the measurement of fasting serum total and ionized $\mathrm{Ca}^{2+}$, PTH, creatinine, phosphate, and magnesium, as well as 24-hour urinary calcium and urinary calcium to creatinine clearance ratio. Family history was negative for hypercalcemia, peptic ulcer, kidney stones, or skeletal manifestations in all cases. Our internal review board approved the study, and written informed consent was obtained from all patients who participated in the study.

Family $\boldsymbol{A}$ The proband (II-3, Fig. 1A) is a 30-year-old man with mild hypercalcemia $(2.63 \mathrm{mmol} / \mathrm{l})$ diagnosed at 27 years of age during routine investigation for a left testicular carcinoma, which was successfully treated by surgery and chemotherapy. Serum PTH was normal (25 ng/l). Serum calcium and PTH were stable thereafter and the patient remains in good health.

Family B The proband (II-3, Fig. 1B) is a 60-year-old woman with mild hypercalcemia $(2.65 \mathrm{mmol} / \mathrm{l})$ detected at 55 years during routine blood tests, which remained stable afterward, and no further investigation was performed up to when she was seen in our outpatient clinic.

Family C The proband (II-2, Fig. 1C) is a 60-year-old woman with hypercalcemia diagnosed at 59 years during a routine evaluation for osteoporosis. Further investigations confirmed hypercalcemia $(2.7 \mathrm{mmol} / \mathrm{l})$, with PTH levels from 34 to $68 \mathrm{ng} / \mathrm{l}$ and normal urinary calcium excretion $(3.4 \mathrm{mmol} / 24 \mathrm{~h})$. Parathyroid imaging studies indicated an abnormal left superior parathyroid gland. The diagnosis of PHPT was made and the left superior parathyroid gland was removed; no other enlarged parathyroid glands were found or biopsied at surgery. The resected gland was macroscopically enlarged $(9 \times 7 \times 3 \mathrm{~mm})$; histology showed diffuse chief cell hyperplasia and a marked reduction of fat cells. There was no evidence of a rim of normal parathyroid tissue surrounding the hyperplastic lesion. The final pathologic report was of parathyroid hyperplasia/possibly adenoma. Serum calcium levels were substantially unchanged after surgery.

Family $\boldsymbol{D}$ The proband (II-1, Fig. 1D) is a 72-year-old woman in whom primary hyperparathyroidism (PHPT) was diagnosed elsewhere (serum calcium $2.68 \mathrm{mmol} / \mathrm{l}$; PTH $68 \mathrm{ng} / \mathrm{l})$. She underwent neck exploration, but no enlarged parathyroid glands were found.

\section{Methods}

Genetic analysis of the CASR gene Leukocyte DNA was isolated using standard methods. Exons 2-7 and adjacent splice sites of the CASR were amplified, and purified PCR products sequenced as described $(18,19)$. The DNA sequences of both strands were determined using an autosequencer (ABI PRISM 310, Genetic Analyzer, PE Applied Biosystems, Foster city, CA, USA).

Sequence alignment The alignment was made using the Clustal W service at http://www.ebi.ac.uk/clusalw/ index.html.

Site-directed mutagenesis The Quick Change SiteDirected mutagenesis kit (Stratagene, La Jolla, CA, USA) was used. For each mutation, the primers were complementary with the mutant sequence placed in the middle. The primers were annealed to the template CASR cDNA (HuPCaR4, kindly provided by Prof. Brown).

\section{Transient expression of the WT and mutated CASRs} in COS-7 cells COS-7 cells were propagated in DMEM as described (19). The cells were plated in Petri dishes and $24 \mathrm{~h}$ later transfected with CASR cDNA (625 and $800 \mathrm{ng}$ for intracellular calcium measurement and immunocytochemical studies respectively) using Lipofectamine 2000 transfection reagent (Invitrogen). For co-expression experiments, equal amounts $(625 \mathrm{ng})$ of WT and mutant CASR cDNAs were mixed and transfected as above.

Functional studies Cells were studied $48 \mathrm{~h}$ after transfection. Cells transfected with pcDNA3 alone were used as controls. Triplicate dishes were used, and each experiment was repeated at least four times. 
A
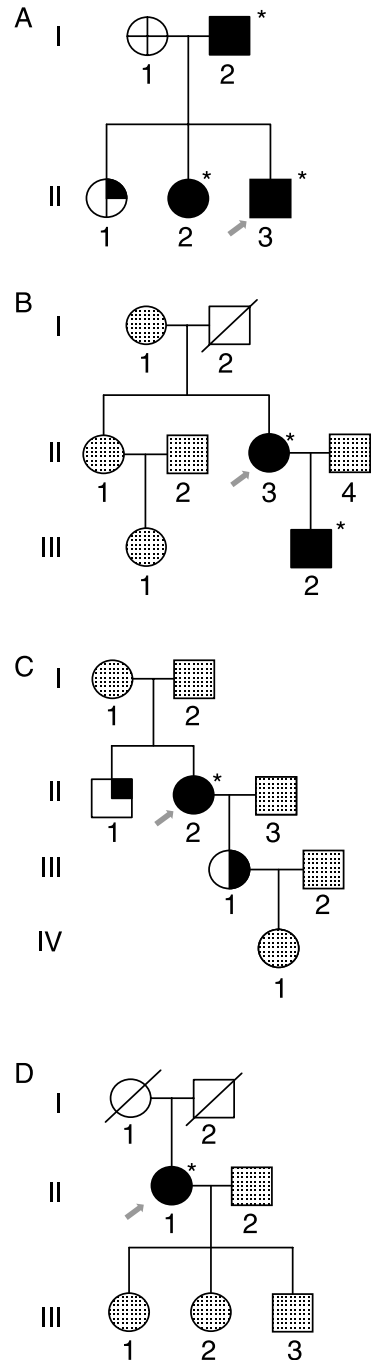
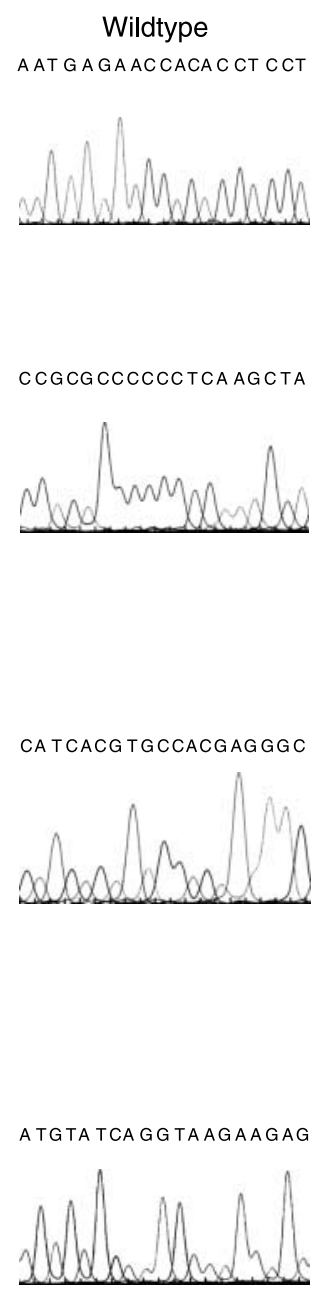

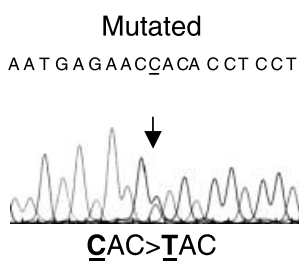

$\mathrm{H} 595 \mathrm{Y}$

CCGCGCCCCEC TCAAGCTA
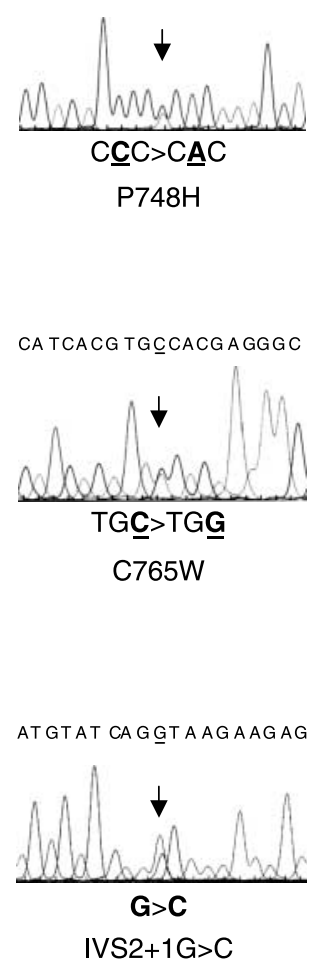

Figure 1 Left panels. Pedigrees and phenotypes of the members of the four kindreds with $\mathrm{FHH}$. Circles, women; squares, male; filled symbols, affected by FHH; quartered symbols, individuals submitted to complete or partial clinical assessment: upper right filled quarter indicates hypercalcemia; lower right filled quarter indicates urinary $\mathrm{Ca} / \mathrm{Cr}$ clearance ratio $\leq 0.01$; dotted symbols, unknown with regard to phenotype and genotype; slashed symbols, deceased; arrow, proband. *Subjects submitted to DNA testing. Right panels. DNA sequences of wildtype and mutated CASRs. The sequence of the sense strand is shown.
Intracellular calcium $\left[\mathrm{Ca}^{2+} \boldsymbol{I}_{i}\right.$ measurement $\operatorname{COS}-7$ cells were detached from Petri dishes by trypsinization and loaded for $30 \mathrm{~min}$ at $37^{\circ} \mathrm{C}$ with fura-2/AM $(2 \mu \mathrm{M})$, as described $(20,21)$. Cells were pelleted, resuspended in $\mathrm{Ca}^{2+}$ - and $\mathrm{Mg}^{2+}$-free HBSS/HEPES, and transferred to a quartz thermostatted cuvette $\left(37^{\circ} \mathrm{C}\right)$. Extracellular $\mathrm{Ca}^{2+}$ concentration $\left[\mathrm{Ca}^{2+}\right]_{0}$ was varied by adding $\mathrm{CaCl}_{2}$. The fluorescence intensity was quantified with a LS-50B Luminescence Spectrometer (Perkin-Elmer, Norwalk, CT, USA) at $340 \mathrm{~nm}$ (F340) and $380 \mathrm{~nm}$ $(\mathrm{F} 380 \mathrm{~nm})$, and emission wavelength was monitored at $510 \mathrm{~nm}$. The photomultiplier was coupled to a personal computer equipped with the Perkin-Elmer FL WinLab software for data acquisition. An increment of $\left[\mathrm{Ca}^{2+}\right]_{\mathrm{i}}$ induces an increase in F340 and a decrease in F380, resulting in an increase in F340/F380. Data were analyzed by setting the basal fluorescence (F340/F380) as $100 \%$. Results (mean \pm s.E.M.) are expressed as a percentage of the maximal response obtained for the
WT or each mutant receptor. The $\mathrm{EC}_{50}$ (concentration producing half the maximum effect) was determined by non-linear regression curve analysis of the doseresponse curves using the software GraphPad Prism (GraphPad Software, La Jolla, CA, USA). The $E_{\max }$ (percentage of the maximal CASR WT response) was also calculated for each mutant. Differences in $\mathrm{EC}_{50}$ and $E_{\max }$ values among dose-response curves were calculated with the F test and ANOVA followed by the NewmanKeuls multiple comparison post-test respectively.

Fluorescence immunocytochemistry and confocal microscopy Cells were harvested after incubation at $37^{\circ} \mathrm{C}$ for $5 \mathrm{~min}$ with trypsin (Gibco), and about $10^{5}$ cells were seeded on six-well Petri dishes containing a coverslip and used at $90 \%$ confluence. Cells were fixed in $4 \%$ paraformaldehyde. Cells were permeabilized in $0.2 \%$ Triton X-100 in PBS for 15 min and incubated with blocking solution (PBS containing 5\% normal goat 
serum, 5\% BSA, 0.1\% Tween). After washing, cells were incubated with the primary monoclonal human CASR antibody (ADD, Abcam, Cambridge, UK) at the dilution of 1:500 in blocking solution for $2 \mathrm{~h}$. After washing, the cells were incubated with the secondary goat anti-mouse antibody (1:3000) for $1 \mathrm{~h}$. Then cells were incubated with DAPI (Santa Cruz Biotechnology, Santa Cruz, CA, USA) for 2 min and immediately washed twice with PBS. All steps were performed at room temperature. Before mounting onto slides, the coverslips were washed five times with water and allowed to dry. Coverslips were mounted onto microscope slides using Pro-Long Antifade Kit (Molecular Probes, Invitrogen Corporation) and examined under an inverted microscope (Nikon Eclipse TE300) equipped with a laser confocal scanning system (Radiance Plus, Bio-Rad).

\section{Results}

All clinical, biochemical, genetic, and in vitro studies were performed at our institution.

All patients underwent the standard clinical and biochemical evaluation we perform for the differential diagnosis of hypercalcemia. Hypercalcemia was confirmed in all probands (Table 1). Serum PTH was normal in two probands and mildly elevated in the other two. Twenty-four hour urinary calcium excretion was inappropriately low for the corresponding serum calcium concentration, and the calcium/creatinine clearance ratio was $<0.01$ in all probands, raising the suspicion of $\mathrm{FHH}$. Biochemical data were also obtained in the available family members and the genetic analysis was performed in all but four cases who refused to participate in the study. Besides the probands, three additional genetically confirmed cases of $\mathrm{FHH}$ were identified (I-2 and II-2 of family A and III-2 of family B). Moreover, three other subjects (II-1 in family A and II-1 and III-1 in family C) were hypercalcemic and thus potentially affected, but the diagnosis of FHH could not be definitively established because they refused the genetic analysis. No patients or family members had a history of peptic ulcer, pancreatitis, kidney stones, renal parenchymal damage, or fractures.

\section{Genetic analysis of the CASR gene}

The entire coding sequence and splice junctions of the CASR gene were sequenced in the probands, and four unreported CASR mutations were found. These mutations were not detected by direct sequencing of the region of interest in any of 50 unrelated healthy subjects of Italian origin.

In the proband of family $A$, a novel heterozygous base substitution $\mathrm{C}$ to $\mathrm{T}$ was detected, producing a change of histidine to tyrosine at codon 595 (H595Y) of exon 7. This mutation was located in the extracellular domain of the CASR. The same heterozygous mutation was found in two other affected members of the family (I-2 and II-2).

In family $\mathrm{B}$, there was a heterozygous $\mathrm{C}$ to $\mathrm{A}$ substitution in exon 7 causing a change of proline to histidine $(\mathrm{P} 748 \mathrm{H})$. This mutation was located in the second extracellular loop. Direct sequencing of the region of interest of exon 7 revealed the same heterozygous mutation in another affected family member (III-2).

In the proband of family $\mathrm{C}$, a heterozygous $\mathrm{C}$ to $\mathrm{G}$ substitution, producing a change of cysteine to tryptophan at codon $765(\mathrm{C} 765 \mathrm{~W})$ of exon 7, was detected. This mutation, also located in the second extracellular loop, led to the loss of a BglI site providing a convenient diagnostic test to confirm the presence of the mutation in the proband and other family members.

In the proband of family D, there was a heterozygous $\mathrm{G}$ to $\mathrm{C}$ substitution in the donor splice site of intron 2 $($ IVS $2+1 G>C)$. This mutation would lead to a disruption of the splice site preventing proper excision of the intron.

\section{Functional studies}

Effects on $\left[\mathbf{C a}^{2+} \boldsymbol{I}_{\boldsymbol{i}}\right.$ As shown in Fig. 2(A and B), COS-7 cells transfected with WT CASR had a threshold for a response to $\left[\mathrm{Ca}^{2+}\right]_{0}$ between 0.5 and $1.0 \mathrm{mM}$. In addition, increments in $\left[\mathrm{Ca}^{2+}\right]_{0}$ from the threshold level produced rapid followed by sustained increases of basal fluorescence (F340/F380) with a sigmoidal concentration-response curve $\left(\mathrm{EC}_{50}=2.11 \pm 0.03 \mathrm{mM}\right.$; $E_{\text {max }}=128.3 \pm 0.9 \%$; Fig. 2D). As expected, the increase of F340/F380 after exposure of the cells to the maximal $\left[\mathrm{Ca}^{2+}\right]_{\mathrm{o}}(10 \mathrm{mM})$ was due to an increase of F340 and a decrease of F380, thus representing a specific increase of $\left[\mathrm{Ca}^{2+}\right]_{\mathrm{i}}$ (Fig. 2B). In particular, in COS-7 cells transfected with WT CASR, $\left[\mathrm{Ca}^{2+}\right]_{\mathrm{i}}$ increased from a baseline value of $\sim 60 \pm 4$ up to $\sim 100 \pm 6 \mathrm{nM}$, while no change in $\left[\mathrm{Ca}^{2}+\right]_{\mathrm{i}}$ was observed in non-transfected COS-7 cells (Fig. 2C), indicating the specific involvement of CASR in our $\left[\mathrm{Ca}^{2+}\right]_{\mathrm{i}}$ responses.

As shown in Fig. 2E and Table 2, the P748H and H595Y mutants had concentration-response curves shifted to the right with lower maximal responses relative to that of WT. By contrast, the co-transfected $\mathrm{WT} / \mathrm{P} 748 \mathrm{H}$ and $\mathrm{WT} / \mathrm{H} 595 \mathrm{Y}$ had the same behavior as the WT receptor. The $\mathrm{C} 765 \mathrm{~W}$ mutant had a concentration-response curve shifted to the right and the co-transfected WT/C765W had the same $\mathrm{EC}_{50}$ as the WT. The maximal responses of $\mathrm{C} 765 \mathrm{~W}$ and co-transfected WT/C765W, however, relative to that of WT were both lower. The co-transfection results, if reflective of what happens in vivo, would suggest that the mutated receptors do not exert a dominant-negative effect manifested by an increase in $\mathrm{EC}_{50}$, but in the case of 
Table 1 Clinical, biochemical, and genetic findings in the subjects who participated in the study.

\begin{tabular}{|c|c|c|c|c|c|c|c|c|c|c|}
\hline Families & $\begin{array}{l}\text { Age (year) at } \\
\text { diagnosis/sex }\end{array}$ & $\begin{array}{c}\text { Total } \\
\text { calcium } \\
(\mathrm{mmol} / \mathrm{l})\end{array}$ & $\begin{array}{l}\text { lonized } \\
\text { calcium } \\
(\mathrm{mmol} / \mathrm{l})\end{array}$ & $\begin{array}{l}\text { PTH } \\
\text { (ng/l) }\end{array}$ & $\begin{array}{l}\text { 25OHD } \\
(\mathrm{nmol} / \mathrm{l})\end{array}$ & $\begin{array}{l}\text { Phosphate } \\
\text { (mmol/l) }\end{array}$ & $\underset{(\mathrm{nmol} / \mathrm{l})}{\text { Magnesium }}$ & $\begin{array}{c}\text { Urinary } \\
\text { calcium } \\
(\mathrm{mmol} / 24 \mathrm{~h})\end{array}$ & $\begin{array}{l}\text { Urinary } \mathrm{Ca} / \mathrm{Cr} \\
\text { clearance }^{\text {ratio }} \\
\text { rati }^{\mathrm{a}}\end{array}$ & $\begin{array}{c}\text { CASR } \\
\text { genotype }\end{array}$ \\
\hline \multicolumn{11}{|l|}{ A } \\
\hline $11-3^{b}$ & $30 / \mathrm{M}$ & 2.63 & 1.43 & 18 & 61.9 & 1.06 & 0.82 & 3.1 & 0.007 & $\mathrm{H} 595 \mathrm{Y}$ \\
\hline $\mathrm{I}-1$ & $55 / \mathrm{F}$ & 2.35 & $N A^{c}$ & - & - & - & - & - & - & $N D^{d}$ \\
\hline $\mathrm{I}-2$ & $55 / \mathrm{M}$ & 2.58 & - & 54 & - & 1.10 & 0.82 & 3.6 & 0.010 & $\mathrm{H} 595 \mathrm{Y}$ \\
\hline $\mathrm{II}-1$ & $30 / F$ & 2.60 & - & 32 & - & 1.19 & 0.90 & 4.4 & 0.015 & ND \\
\hline II-2 & $33 / F$ & 2.50 & - & 20 & - & 1.10 & 0.74 & 3.0 & 0.010 & $\mathrm{H} 595 \mathrm{Y}$ \\
\hline \multicolumn{11}{|l|}{$B$} \\
\hline $11-3^{b}$ & $60 / F$ & 2.68 & 1.49 & 37 & 80.9 & - & 0.95 & 3.0 & 0.007 & $\mathrm{P} 748 \mathrm{H}$ \\
\hline III-2 & $30 / \mathrm{M}$ & 2.70 & 1.47 & 30 & - & - & - & - & - & $\mathrm{P} 748 \mathrm{H}$ \\
\hline \multicolumn{11}{|l|}{ C } \\
\hline $11-2^{b}$ & $61 / F$ & 2.70 & 1.47 & 71 & 27.7 & 0.94 & 0.95 & 2.1 & 0.008 & C765W \\
\hline$\| \mid-1$ & $63 / M$ & 2.68 & - & - & - & - & - & - & - & ND \\
\hline III-1 & $33 / \mathrm{F}$ & 2.70 & - & 54 & - & 0.90 & - & 4.8 & 0.006 & ND \\
\hline \multicolumn{11}{|l|}{ D } \\
\hline$I I-1^{b}$ & $71 / F$ & 2.53 & 1.37 & 88 & 42 & 1.06 & 0.95 & 1.7 & 0.004 & IVS $2+1 G>C$ \\
\hline Normal range & & $2.05-2.55$ & $1.12-1.32$ & $10-65$ & $62-150$ & $0.87-1.45$ & $0.70-1.07$ & 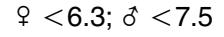 & & \\
\hline
\end{tabular}

F, female; M, male.

${ }^{a} U_{\mathrm{Ca}_{a}} \mathrm{~S} \mathrm{~S}_{\mathrm{Cr}} / \mathrm{UCr}$, where $\mathrm{U}_{\mathrm{Ca}}, \mathrm{U}_{\mathrm{Cr}}, \mathrm{S}_{\mathrm{Ca}}$ and $\mathrm{S}_{\mathrm{Cr}}$ are the 24-h urinary excretions of calcium and creatinine and the serum total calcium and creatinine concentration, respectively. Values below 0.01 are typically found in patients with $\mathrm{FHH}$.

Proband.

NA, Not available.

dND, not done because of patient refusal. 

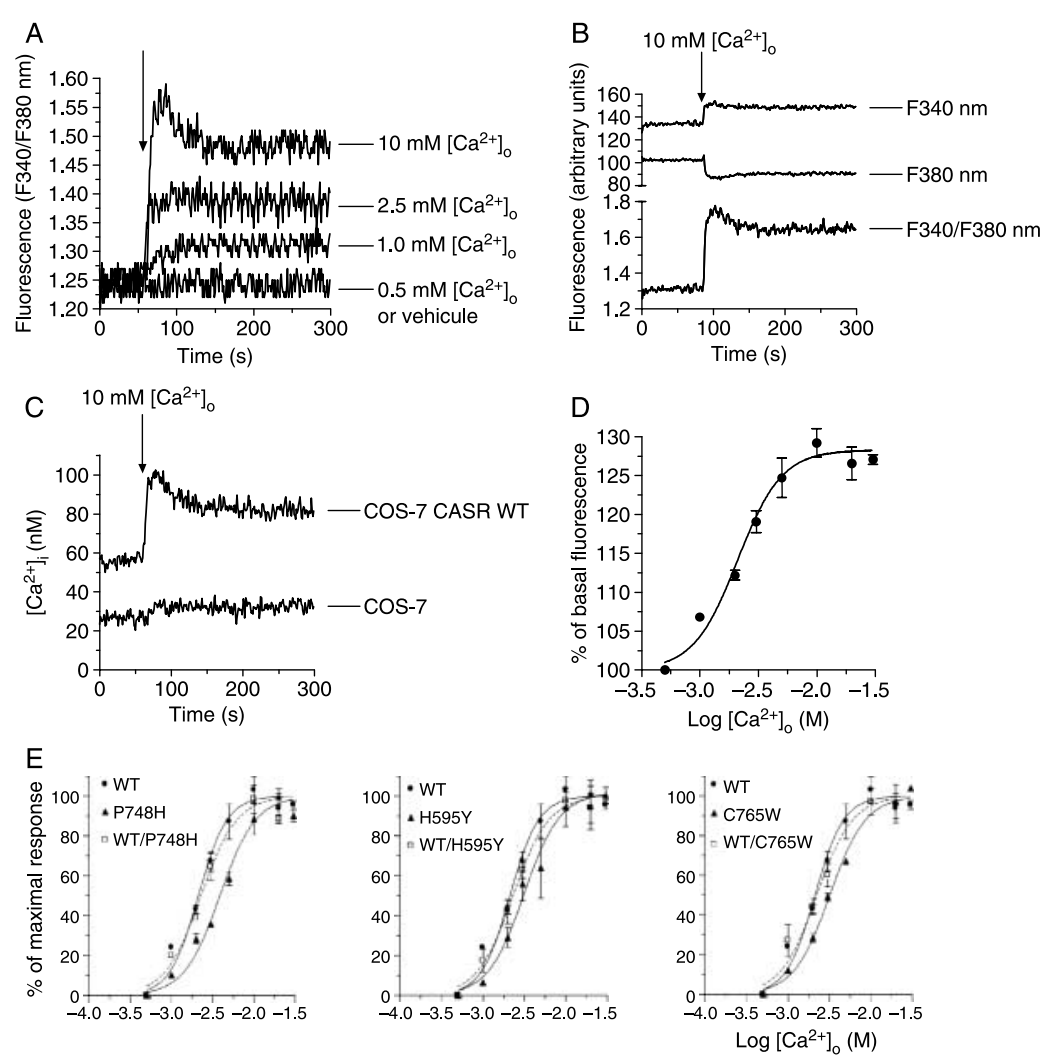

Figure $2\left[\mathrm{Ca}^{2+}\right]_{i}$ response of COS-7 cells transfected with wildtype (WT) or mutant CASRs to $\left[\mathrm{Ca}^{2+}\right]_{0} .(\mathrm{A}-\mathrm{C})$ Each trace shown is typical of the recording made in multiple (at least four) independent experiments using COS-7 cells transfected with WT CASR. (D) Effect of increasing $\left[\mathrm{Ca}^{2+}\right]_{0}$ on basal fluorescence (F340/F380) in COS-7 cells transfected with WT. (E) Effect of increasing $\left[\mathrm{Ca}^{2+}\right]_{\mathrm{o}}$ in $\mathrm{COS}-7$ cells transfected with WT, mutated, and co-transfected CASRs. The results (mean \pm S.E.M.) are expressed as a percentage of the maximal value obtained for each mutant in at least four experiments.
C765W reduce the maximal activation of the WT receptor (Table 2). The CASR gene mutated in the donor splice site in family $\mathrm{D}$ could not be tested because the splice product(s), if any, formed in vivo as a result of this mutation are unknown.

Fluorescence immunocytochemistry and confocal microscopy Experiments were performed using nonpermeabilized cells to identify cell surface staining (positive staining indicates normal receptor processing; negative staining indicates trapping within the cell) and permeabilized cells to identify the receptor trapped within the cell, Fig. 3.

Table 2 Parameters of $\left[\mathrm{Ca}^{2+}\right]_{i}$ response to changes of $\left[\mathrm{Ca}^{2+}\right]_{0}$ in cells transfected with wildtype and mutated CASRs.

\begin{tabular}{lcccc}
\hline \multicolumn{1}{c}{ Clone } & EC $_{\mathbf{5 0}}(\mathrm{mM})$ & $\boldsymbol{P}^{\mathrm{a}}$ & $\boldsymbol{E}_{\max }(\% \mathrm{WT})$ & $\boldsymbol{P}^{\mathrm{a}}$ \\
\hline Wildtype (WT) & $2.11 \pm 0.03^{\mathrm{b}}$ & - & 100 & \\
H595Y & $2.64 \pm 0.05$ & $<0.001$ & $69.4 \pm 3.5$ & $<0.001$ \\
WT/H595Y & $2.31 \pm 0.04$ & $\mathrm{NS}$ & $103.8 \pm 4.3$ & $\mathrm{NS}$ \\
P748H & $3.87 \pm 0.03$ & $<0.001$ & $72.3 \pm 3.1$ & $<0.001$ \\
WT/P748H & $2.29 \pm 0.04$ & NS & $104.1 \pm 4.9$ & NS \\
C765W & $3.20 \pm 0.01$ & $<0.001$ & $61.2 \pm 2.7$ & $<0.001$ \\
WT/C765W & $2.23 \pm 0.05$ & NS & $66.2 \pm 3.6$ & $<0.001$ \\
\hline
\end{tabular}

WT, wildtype.

${ }^{\mathrm{a} C}$ Compared to WT.

${ }^{b}$ Values are means \pm S.E.M. of at least four different experiments.
Non-permeabilized cells transfected with the WT receptor showed strong staining at the cell surface. Permeabilization of these cells revealed additional perinuclear staining. Non-permeabilized cells transfected with $\mathrm{H} 595 \mathrm{Y}, \mathrm{C} 765 \mathrm{~W}$, and P748H mutants showed a pattern similar to that of the WT, indicating normal CASR trafficking from endoplasmic reticulum to the membrane. In permeabilized cells transfected with the $\mathrm{H} 595 \mathrm{Y}, \mathrm{P} 748 \mathrm{H}$, and $\mathrm{C} 765 \mathrm{~W}$ mutants, perinuclear staining associated with the Golgi apparatus and the endoplasmic reticulum similar to that of the WT cells was observed.

\section{Discussion}

We describe four $\mathrm{FHH}$ families with four previously unreported CASR mutations. The clinical features of the probands and affected family members were consistent with the diagnosis of FHH. Indeed, all had mild asymptomatic hypercalcemia associated with normal or slightly elevated serum PTH values. The mildly elevated serum PTH levels in the probands of families C and $\mathrm{D}$ led to the initial mistaken diagnosis of sporadic PHPT and therefore to parathyroid surgery. A mildly enlarged parathyroid gland was removed in the former and was histologically scored as a hyperplastic gland, possibly a parathyroid adenoma. The microscopic 
Non-permeabilized

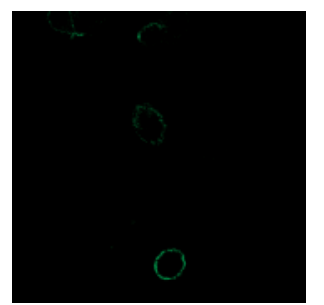

Permeabilized

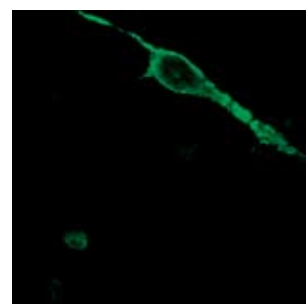

WT
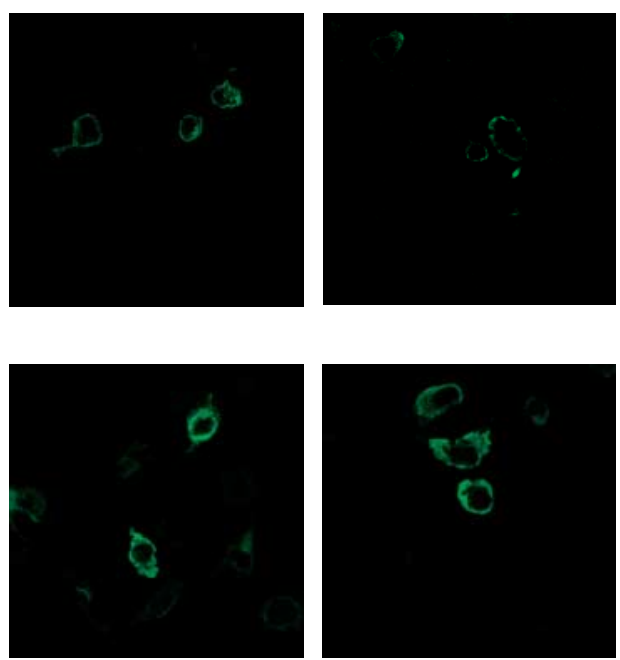

H595Y

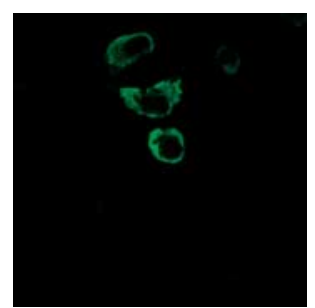

C765W
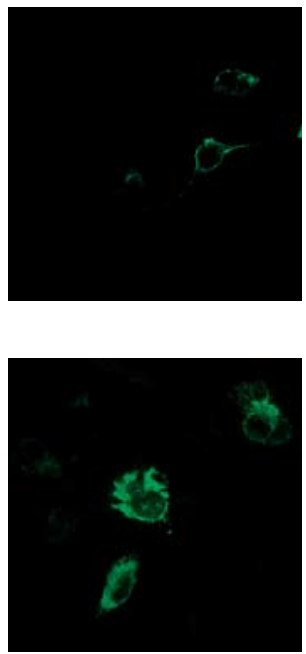

$\mathrm{P} 748 \mathrm{H}$

Figure 3 Expression of wildtype and mutant CASRs in transfected COS-7 cells using fluorescence immunocytochemistry and confocal microscopy. Examples of fields of non-permeabilized (upper panel) and permeabilized (lower panel) cells. Magnification: $600 \times$.

appearance was not consistent with the so-called 'lipohyperplasia', which has been reported in several parathyroid glands of $\mathrm{FHH}$ patients, where, at variance with what we found in our case, concurrent hyperplasia of fat and parathyroid chief cells have been observed in some cases $(22,23)$. Thus, we believe that the resected parathyroid gland was pathological. Whether the anatomic lesion was truly hyperplasia or an adenoma remains unclear. The normal macroscopic appearance of the other parathyroid glands at neck exploration might favor the latter diagnosis. On the other hand, in the absence of the histological demonstration that the apparently unaffected glands were normal, diffuse hyperplasia cannot be excluded. Serum calcium levels were unchanged after surgery suggesting that abnormal calcium-regulated PTH secretion by the enlarged parathyroid gland was readily taken over by the remaining, presumably functionally abnormal, parathyroid glands. At variance with our case, the removal of a large parathyroid adenoma, which was associated with marked symptomatic hypercalcemia in a subject with $\mathrm{FHH}$, was followed by an initial rapid decrease in serum calcium to normal levels, followed by a recurrence of mild hypercalcemia characteristic of FHH (24). Parathyroid adenomas have also been reported in several members of an atypical $\mathrm{FHH}$ family described by Carling and coworkers (25).

The question of whether the finding of a parathyroid adenoma in subjects with $\mathrm{FHH}$ is coincidental or secondary to the CASR mutations remains to be established. However, somatic inactivating mutations of the CASR gene are not present in sporadic parathyroid adenomas $(18,26)$, suggesting that co-occurrence by chance of PHPT and FHH, although very rare, accounts for the association in occasional cases. By contrast, a causal role of a CASR mutation in the development of parathyroid adenomas has been proposed in the kindred described by Carling et al. (25). Indeed, in this family all abnormal glands displayed allelic losses at loci commonly involved in sporadic parathyroid tumors, and the authors suggested that the germline CASR mutation may increase the susceptibility to secondary genetic hits, at least with this specific mutation in the receptor's C-terminal tail (27).

Molecular analysis showed that all four kindreds carried unreported CASR mutations. Three of them (H595Y, P748H, and C765W) were missense and involved amino acids highly conserved between species. The fourth was a splice site mutation in intron 2 $(\mathrm{IVS} 2+1 \mathrm{G}>\mathrm{C})$ and, to our knowledge, is the second splice site mutation identified in the CASR gene. The first mutation (IVS2-1G $>$ T) was identified in a family with FHH (10). This mutation resulted in exon 3 skipping, causing a shift in the reading frame of exon 4 and the introduction of a premature stop codon leading to a predicted truncated protein of 153 amino acids. The splice site mutation IVS $2+1 \mathrm{G}>\mathrm{C}$ described herein would most likely give little or no CASR mRNA or partially spliced mRNA and probably no protein. None of the four mutations we describe herein was located in the so-called cysteine-rich domain, which plays a critical role in the interaction between the "Venus flytrap' domain and the seven transmembrane domains $(28,29)$.

Functional characterization of the CASR mutations was performed by transfecting WT and mutated CASRs into COS-7 cells. All mutations caused substantially reduced maximal responses to $\left[\mathrm{Ca}^{2+}\right]_{\mathrm{o}}$. These results are consistent with the inactivating nature of these CASR mutations. Although these mutations only 
modestly altered the $\mathrm{EC}_{50}$ for extracellular calciumevoked increases in $\left[\mathrm{Ca}^{2+}\right]_{\mathrm{i}}$, compared with other mutations (30-32), the combination of reduced maximal responses and increased $\mathrm{EC}_{50} \mathrm{~s}$ produced significantly impaired functional responses in vitro and were clearly associated with defective $\left[\mathrm{Ca}^{2+}\right]_{0}$-sensing in vivo.

To further investigate the mechanisms responsible for the loss of function of mutated CASRs, fluorescence immunocytochemistry was performed on COS-7 cells transiently transfected with WT and mutated CASR cDNAs. These studies showed that all mutants were expressed at levels comparable with that of the WT both in non-permeabilized and permeabilized cells, as assessed by fluorescence intensity. These data suggest that the mutated receptors were properly trafficked to the cell surface. Thus, the loss of function of these receptors is likely due to conformational changes that decrease their responses to $\left[\mathrm{Ca}^{2+}\right]_{o}$, without affecting their immunoreactivity, rather than to a reduced receptor number on the cell surface. In this regard, it is worth noting that all three of these mutations were located in the extracellular domain. The proline to histidine substitution at codon 748 and of cysteine to tryptophan at codon 765 and, consequently, the introduction of the aromatic side chains of histidine and tryptophan might alter the polarity of the protein. Moreover, a single mutation from the small and flexible amino acids, proline and cysteine to the larger amino acids, histidine and tryptophan, could also induce conformational changes of the respective receptor proteins.

As our patients harbored heterozygous CASR mutations, co-transfection of COS-7 cells with both WT and mutated receptors was performed to mimic in vitro heterozygosity. The $\mathrm{EC}_{50}\left[\mathrm{Ca}^{2+}\right]_{0}$ and the $E_{\max }$ of WT/H595Y and WT/P748H were similar to those of the WT receptor suggesting that these mutant receptors, which have a pattern of protein expression similar to that of the wildtype, do not exert a dominant-negative effect. Because patients belonging to kindreds A and B have a mild degree of hypercalcemia, it is conceivable that the mutated CASRs, being less sensitive to extracellular calcium, are only minimally activated at ambient blood calcium levels in vivo, and CASR signaling is limited to the reduced complement of remaining normal receptors. Indeed, the biochemical profile of these patients is similar to that observed in the heterozygous CASR knock-out mice (13). These mice have about half of the normal amount of CASR in parathyroid and kidney (haploinsufficiency), and this results in hypocalciuric hypercalcemia of a mild degree. On the other hand, cells co-transfected with the WT and C765W, which is also expressed at the cell surface in a manner similar to that of the WT CASR, showed a decreased $E_{\max }$ compared with WT but a similar $\mathrm{EC}_{50}$ $\left[\mathrm{Ca}^{2+}\right]_{0}$, suggesting that it may reduce the effective concentration of the functional WT CASR on the cell surface or otherwise impair the maximal signaling capacity of the normal CASR.

In conclusion, we have identified unreported heterozygous loss-of-function mutations in the extracellular domain of the CASR gene in four Italian families with FHH. Functional analysis of three mutant CASRs provided an explanation for the clinical phenotype in the patients. A reduced response to calcium stimulation and the finding of normal cell surface expression of the mutant receptors suggest that conformational changes account for altered CASR activity. Moreover, a reduced complement of normal CASRs in these heterozygous patients, perhaps combined in one case with a mutant receptor-induced decrease in maximal activity of the WT receptor, may contribute to defective calciumsensing in vivo.

\section{Declaration of interest}

The authors declare that there is no conflict of interest that could be preceived as prejudicing the impartiality of the scientific work reported.

\section{Funding}

This work was supported in part by the University of Pisa (to C Marcocci), the Ministero dell'Università e della Ricerca Scientifica e Tecnologica (to C Marcocci), and the Ministero della Sanità, Ricerca Oncologica 2006 (RF06ED01) (to C Marcocci).

\section{Acknowledgements}

We are grateful to all family members who graciously agreed to participate in the study.

\section{References}

1 Marx SJ, Attie MF, Levine MA, Spiegel AM, Downs RW Jr \& Lasker RD. The hypocalciuric or benign variant of familial hypercalcemia: clinical and biochemical features in fifteen kindreds. Medicine $198160397-412$.

2 Auwerx J, Demedts M \& Bouillon R. Altered parathyroid set point to calcium in familial hypocalciuric hypercalcaemia. Acta Endocrinologica 1984106 215-218.

3 Brown EM \& MacLeod RJ. Extracellular calcium sensing and extracellular calcium signaling. Physiological Reviews 200181 239-297.

4 Pollak MR, Brown EM, Chou YH, Hebert SC, Marx SJ, Steinmann B, Levi T, Seidman CE \& Seidman JG. Mutations in the human $\mathrm{Ca}^{2+}$ )-sensing receptor gene cause familial hypocalciuric hypercalcemia and neonatal severe hyperparathyroidism. Cell 199375 1297-1303.

5 Chou YH, Pollak MR, Brandi ML, Toss G, Arnqvist H, Atkinson AB, Papapoulos SE, Marx S, Brown EM, Seidman JG \& Sedman CE. Mutations in the human $\mathrm{Ca}\left({ }^{2+}\right)$-sensing-receptor gene that cause familial hypocalciuric hypercalcemia. American Journal of Human Genetics 199556 1075-1079.

6 Pidasheva S, D'Souza-Li L, Canaff L, Cole DE \& Hendy GN. CASRdb: calcium-sensing receptor locus-specific database for mutations causing familial (benign) hypocalciuric hypercalcemia, neonatal severe hyperparathyroidism, and autosomal dominant hypocalcemia. Human Mutation 200424 107-111. 
7 Pearce SH, Trump D, Wooding C, Besser GM, Chew SL, Grant DB, Heath DA, Hughes IA, Paterson CR, Whyte MP \& Thakker RV. Calcium-sensing receptor mutations in familial benign hypercalcemia and neonatal hyperparathyroidism. Journal of Clinical Investigation 199596 2683-2692.

8 Jap TS, Wu YC, Jenq SF \& Won GS. A novel mutation in the calcium-sensing receptor gene in a Chinese subject with persistent hypercalcemia and hypocalciuria. Journal of Clinical Endocrinology and Metabolism 200186 13-15.

9 Yamauchi M, Sugimoto T, Yamaguchi T, Yano S, Wang J, Bai M, Brown EM \& Chihara K. Familial hypocalciuric hypercalcemia caused by an R648stop mutation in the calcium-sensing receptor gene. Journal of Bone and Mineral Research 200217 2174-2182.

10 D'Souza-Li L, Canaff L, Janicic N, Cole DE \& Hendy GN. An acceptor splice site mutation in the calcium-sensing receptor (CASR) gene in familial hypocalciuric hypercalcemia and neonatal severe hyperparathyroidism. Human Mutation 200118 411-421.

11 Janicic N, Pausova Z, Cole DE \& Hendy GN. Insertion of an Alu sequence in the $\mathrm{Ca}\left({ }^{2+}\right)$-sensing receptor gene in familial hypocalciuric hypercalcemia and neonatal severe hyperparathyroidism. American Journal of Human Genetics $1995 \mathbf{5 6} 880-886$.

12 Cole DE, Janicic N, Salisbury SR \& Hendy GN. Neonatal severe hyperparathyroidism, secondary hyperparathyroidism, and familial hypocalciuric hypercalcemia: multiple different phenotypes associated with an inactivating Alu insertion mutation of the calcium-sensing receptor gene. American Journal of Human Genetics $199771202-210$.

13 Ho C, Conner DA, Pollak MR, Ladd DJ, Kifor O, Warren HB, Brown EM, Seidman JG \& Seidman CE. A mouse model of human familial hypocalciuric hypercalcemia and neonatal severe hyperparathyroidism. Nature Genetics 199511 389-394.

14 Kifor O, Moore Jr FD, Delaney M, Garber J, Hendy GN, Butters R, Gao P, Cantor TL, Kifor I, Brown EM \& Wysolmerski J. A syndrome of hypocalciuric hypercalcemia caused by autoantibodies directed at the calcium-sensing receptor. Journal of Clinical Endocrinology and Metabolism $2003 \mathbf{8 8} 60-72$.

15 Pallais JC, Kifor O, Chen YB, Slovik D \& Brown EM. Acquired hypocalciuric hypercalcemia due to autoantibodies against the calcium-sensing receptor. New England Journal of Medicine 2004 $351362-369$.

16 Heath III H, Jackson CE, Otterud B \& Leppert MF. Genetic linkage analysis in familial benign (hypocalciuric) hypercalcemia: evidence for locus heterogeneity. American Journal of Human Genetics 199353 193-200.

17 Lloyd SE, Pannett AA, Dixon PH, Whyte MP \& Thakker RV. Localization of familial benign hypercalcemia, Oklahoma variant (FBHOk), to chromosome 19q13. American Journal of Human Genetics 199964 189-195.

18 Cetani F, Pinchera A, Pardi E, Cianferotti L, Vignali E, Picone A, Miccoli P, Viacava P \& Marcocci C. No evidence for mutations in the calcium-sensing receptor gene in sporadic parathyroid adenomas. Journal of Bone and Mineral Research 199914 878-882.

19 Cetani F, Pardi E, Borsari S, Tonacchera M, Morabito E, Pinchera A \& Marcocci C. Two Italian kindreds with familial hypocalciuric hypercalcaemia caused by loss-of-function mutations in the calcium-sensing receptor $(\mathrm{CaR})$ gene: functional characterization of a novel CaR missense mutation. Clinical Endocrinology 200358 199-206.
20 Traina G, Cannistraro S \& Bagnoli P. Effects of somatostatin on intracellular calcium concentration in PC12 cells. Journal of Neurochemistry 199666 485-492.

21 Cervia D, Langenegger D, Schuepbach E, Cammalleri M, Schoeffter P, Schmid HA, Bagnoli P \& Hoyer D. Binding and functional properties of the novel somatostatin analogue KE 108 at native mouse somatostatin receptors. Neuropharmacology 2005 48 881-893.

22 Law WM, Carney JA \& Heath H III. Parathyroid glands in familial benign hypercalcemia (familial hypocalciuric hypercalcemia). American Journal of Medicine 198476 1021-1026.

23 Fukumoto S, Chikatsu N, Okazaki R, Takeuchi Y, Tamura Y, Muratami T, Obara T \& Fujita T. Inactivating mutations of calcium-sensing receptor results in parathyroid lipohyperplasia. Diagnostic Molecular Pathology $200110242-247$.

24 Burski K, Torjussen B, Paulsen AQ, Boman H \& Bollerslev J. Parathyroid adenoma in a subject with familial hypocalciuric hypercalcemia: coincidence or causality? Journal of Clinical Endocrinology and Metabolism 200287 1015-1016.

25 Carling T, Szabo E, Bai M, Ridefelt P, Westin G, Gustavsson P, Trivedi S, Hellman P, Brown EM, Dahl N \& Rastad J. Familial hypercalcemia and hypercalciuria caused by a novel mutation in the cytoplasmic tail of the calcium receptor. Journal of Clinical Endocrinology and Metabolism 200085 2042-2047.

26 Hosokawa Y, Pollak MR, Brown EM \& Arnold A. Mutational analysis of the extracellular $\mathrm{Ca}^{2+}$-sensing receptor gene in human parathyroid tumors. Journal of Clinical Endocrinology and Metabolism $1995 \mathbf{8 0} 3107-3110$.

27 Szabo E, Carling T, Hessman O \& Rastad J. Loss of heterozygosity in parathyroid glands of familial hypercalcemia with hypercalciuria and point mutation in calcium receptor. Journal of Clinical Endocrinology and Metabolism 200287 3961-3965.

28 Hofer AM \& Brown EM. Extracellular calcium sensing and signalling. Nature Reviews. Molecular Cell Biology 20034 530-538.

29 Pin JP, Kniazeff J, Goudet C, Bessis AS, Liu J, Galvez T, Acher F, Rondard P \& Prézeau L. The activation mechanism of class-C G-protein coupled receptors. Biology of the Cell 200496 335-342.

30 Bai M, Quinn S, Trivedi S, Kifor O, Pearce SH, Pollak MR, Krapcho K, Hebert SC \& Brown EM. Expression and characterization of inactivating and activating mutations in the human $\mathrm{Ca}^{2+}$ o-sensing receptor. Journal of Biological Chemistry 1996271 19537-19545.

31 Pearce SH, Bai M, Quinn SJ, Kifor O, Brown EM \& Thakker RV. Functional characterization of calcium-sensing receptor mutations expressed in human embryonic kidney cells. Journal of Clinical Investigation 199698 1860-1866.

32 Wystrychowski A, Pidasheva S, Canaff L, Chudek J, Kokot F, Wiecek A \& Hendy GN. Functional characterization of calciumsensing receptor codon 227 mutations presenting as either familial (benign) hypocalciuric hypercalcemia or neonatal hyperparathyroidism. Journal of Clinical Endocrinology and Metabolism $200590864-870$.

Received 25 November 2008

Accepted 2 December 2008 